\title{
PENGARUH FAKTOR EKSPOSI TERHADAP KUALITAS CITRA RADIOGRAFI
}

\author{
Eif Sparzinanda $^{1^{*}}$, Nehru $^{1}$, dan Nurhidayah ${ }^{1}$ \\ ${ }^{I}$ Program Studi Fisika, Fakultas Sains dan Teknologi, Universitas Jambi, Mendalo Darat 36361 \\ *email: sparzinandae@gmail.com
}

\begin{abstract}
ABSTRAK
Telah dilakukan penelitian pengaruh faktor eksposi terhadap kualitas citra radiografi. Penelitian ini menggunakan phantom, berupa air dalam wadah plastik sebagai pengganti manusia dengan focus film distance (FFD) $100 \mathrm{~cm}$ dan luas lapangan penyinaran $15 \mathrm{~cm} \times 15 \mathrm{~cm}$. Kondisi penyinaran diberikan dengan faktor eksposi meliputi variasi tegangan tabung sebesar $60 \mathrm{kV}, 65 \mathrm{kV}, 70 \mathrm{kV}, 75 \mathrm{kV}, 80 \mathrm{kV}$ biasa disebut dengan teknik standar atau teknik tegangan rutin dan arus waktunya sebesar $20 \mathrm{mAs}, 25 \mathrm{mAs}$ dan $30 \mathrm{mAs}$. Hasil penelitian menunjukkan bahwa kualitas citra akan semakin menurun terhadap penggunaan arus dan waktu yang tinggi. Kualitas citra dapat dilihat pada histogram derajat keabuan menggunakan software platform java Image-J Basics version 1.38 untuk mendapatkan nilai optimum dari faktor eksposi pada kualitas citra.
\end{abstract}

Kata Kunci: Computed Radiography (CR), Kontras, Image-J, Histogram derajat keabuan.

\section{ABSTRACT}

[Titel : The Influence of exposure factors to image radiographic quality] The research on the influence of exposure factor on radiographic image quality has been conducted. This research uses phantom, water in plastic container as human substitute with focus film distance (FFD) $100 \mathrm{~cm}$ and broad field of irradiation $15 \mathrm{~cm} \times 15 \mathrm{~cm}$. The exposure conditions are given by exposure factors including variations in tube voltages of $60 \mathrm{kV}, 65 \mathrm{kV}, 70 \mathrm{kV}, 75 \mathrm{kV}, 80 \mathrm{kV}$ called standard techniques or routine voltage techniques and the time flow is as big as $20 \mathrm{mAs}, 25 \mathrm{mAs}$ and $30 \mathrm{mAs}$. The results showed that the image quality will decrease with the use of current and time high. Image quality can be seen on gray-level histogram using java Image-J Basics version 1.38 software to get optimum value from exposure factor on image quality.

Keywords: Computed Radiography (CR), contrast, image-J, gray-level histogram.

\section{PENDAHULUAN}

Pelayanan kesehatan yang optimal bagi masyarakat memerlukan adanya bidang-bidang penunjang pemeriksaan untuk membantu menegakkan diagnosa suatu penyakit, salah satunya adalah bidang radiologi yang membantu menegakkan diagnosa suatu penyakit dengan memanfaatkan sinar-X yang hasilnya berupa citra radiografi. Menurut Dewi (2009) pemeriksaan radiografi berperan penting dalam menentukan diagnosa dan memantau beberapa hasil perawatan yang dilakukan. Pemeriksaan radiografi merupakan salah satu pemeriksaan identifikasi struktur anatomi tubuh, karena pemeriksaan radiografi dapat memberikan gambaran dari struktur anatomis secara visual.

Pemeriksaan radiografi terhadap anatomi tubuh dapat memberikan informasi semaksimal mungkin yang mudah ditentukan ahli Radiolog diperlukan kualitas citra radiografi yang baik. Kualitas radiografi sangat berpengaruh dalam penentuan ketepatan diagnosa suatu penyakit bidang radiodiagnostik (Dhahryan dan Azam,
2009). Untuk dapat menghasilkan radiografi yang memberikan informasi semaksimal mungkin diperlukan radiografi yang optimal. Kualitas radiografi meliputi densitas, kontras, ketajaman dan distorsi maka perlu dilakukan usaha-usaha untuk menekan faktor-faktor yang dapat menurunkan kualitas radiografi (Ningtias et al., 2016).

Penurunan kualitas citra radiografi disebabkan oleh berbagai faktor, salah satunya adalah radiasi hamburan. Efek radiasi hambur tidak berpola ini dapat mengurangi kontras radiografi (Boddy, 2013). Radiasi hamburan yang sampai ke film mengakibatkan penurunan kualitas citra radiografi karena kenaikan tegangan dan arus tabung serta penambahan luas lapangan radiasi.

Faktor lain yang menentukan kualitas radiografi yaitu faktor eksposi. Faktor eksposi adalah faktor yang mempengaruhi dan menentukan kualitas dan kuantitas dari penyinaran radiasi sinar$\mathrm{X}$ yang diperlukan dalam pembuatan gambar radiografi (Sartinah et al., 2008). Faktor eksposi terdiri dari tegangan tabung $(\mathrm{kV})$, arus tabung 
(mA), dan waktu penyinaran (s) (Rasad, 2005). Pengaturan faktor eksposi yang tepat dapat menghasilkan kontras radiografi yang optimal yaitu mampu menunjukkan perbedaan derajat kehitaman yang jelas antar organ yang mempunyai kerapatan berbeda (Dhahryan dan Azam, 2009). Pemberian faktor eksposi yang tepat dapat mengurangi paparan radiasi yang diserap dengan memperhatikan hasil visual kualitas citra radiografi.

Dalam penelitian ini, pemeriksaan radiografi yang digunakan yaitu radiografi konvensional dalam pemanfaatannya menggunakan pesawat mobile sinar-X dan computed radiography (CR) untuk mendapatkan hasil gambar yang diinginkan dalam bentuk radiografi digital.

\section{METODOLOGI PENELITIAN}

\section{Bahan Penelitian}

Adapun alat yang digunakan dalam penelitian ini adalah pesawat mobile Sinar-X dengan merk pesawat Villa Sistemi Medicalli type/model pesawat Visitor T30C, seperangkat Computed Radiography (CR) dan kaset CR. Sedangkan bahan yang digunakan berupa phantom air yang dimasukkan kedalam plastik.

\section{Pengeksposan Objek}

Pengeksposan objek dilakukan dengan persiapan alat dan bahan, menempatkan objek diatas pertengahan kaset CR yang telah diletakkan di atas meja pemeriksaan, lalu mengatur jarak objek dari tabung $100 \mathrm{~cm}$ denga luas lapangan penyinaran pada kolimator $15 \mathrm{~cm} \times 15 \mathrm{~cm}$. Faktor eksposi diatur dengan variasi tegangan tabung 60 $\mathrm{kV}, 65 \mathrm{kV}, 70 \mathrm{kV}, 75 \mathrm{kV}, 80 \mathrm{kV}$ dan arus waktunya sebesar $20 \mathrm{mAs}, 25 \mathrm{mAs}$ dan $30 \mathrm{mAs}$.

\section{Memproses Citra Radiografi}

Kaset CR yang telah di eksposi akan membentuk bayangan laten dibaca perangkat Computed Radiography dengan imaging plate reader.
Bayangan laten diubah menjadi cahaya tampak melalui scanner pada imaging plate reader. Cahaya ini kemudian diubah menjadi sinyal digital/listrik, selanjutnya dideteksi dan dikirim melalui analog digital converter kekomputer untuk diproses.

\section{Analisis Data}

Analisa yang dilakukan berdasarkan prameter-parameter visualisasi citra dan histogram derajat keabuan. Analisa dilakukan terhadap kontras (Contrast) dan ketajaman citra (Sharpness). Pada analisa histogram derajat keabuan akan diperoleh informasi tentang distribusi intensitas derajat keabuan citra berdasarkan distribusi gray level menggunakan software platform java Image-J Basics version 1.38.

\section{HASIL DAN PEMBAHASAN}

\section{Hasil Citra Radiografi Secara Visual}

Penelitian ini dilakukan untuk mengetahui pengaruh dan nilai optimum faktor eksposi dari citra radiografi dengan menggunakan indikator histogram untuk melihat derajat keabuan suatu citra radiografi. Disajikan data hasil penelitian berupa citra radiografi dari phantom air di Instalasi Radiologi RSUD Raden Mattaher Jambi yang dilakukan pada bulan Agustus 2016. Pengeksposan dilakukan dengan variasi tegangan tabung, arus dan waktu eksposi menggunakan pesawat mobile Sinar- $X$ dengan merk pesawat Villa Sistemi Medicalli type/model pesawat Visitor T30 C.

Analisis kualitas citra dilakukan berdasarkan parameter-parameter visualisasi (pengamatan) citra yang meliputi kontras (contrast) dan ketajaman citra (sharpness). Ukuran citra radiografi yang diperoleh yaitu $2868 \times 3460$ piksel dengan resolusi 8 -bit ditampilkan dan disimpan dalam format JPEG Image (.jpg). Hasil dari setiap citra radiografi phantom air yang telah dilakukan pengeksposan adalah sebagai berikut. 


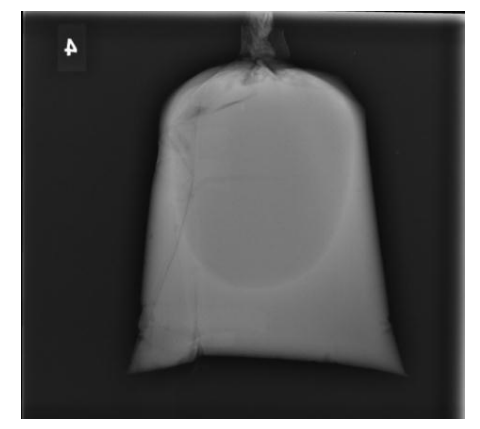

(a)

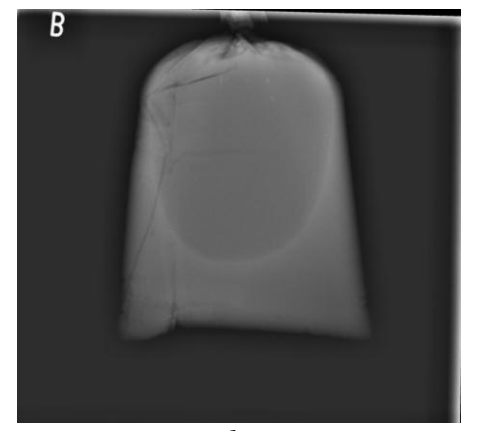

(b)

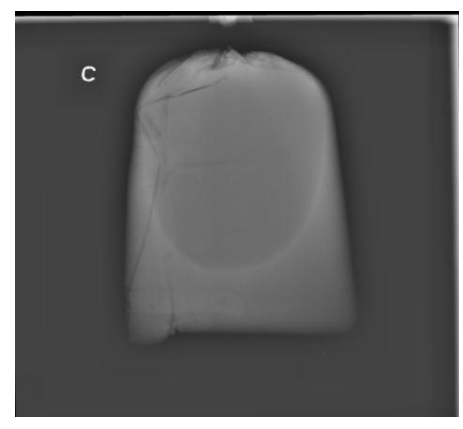

(c)

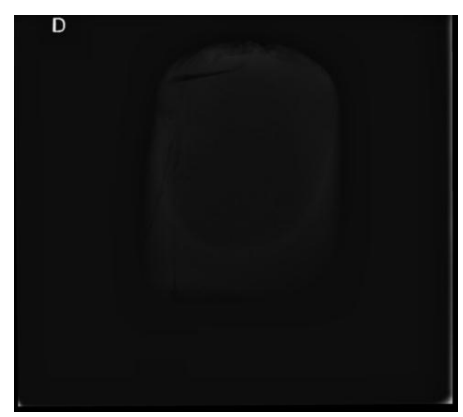

(d)

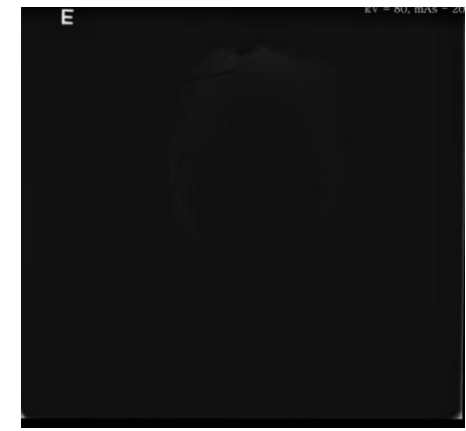

(e)

Gambar 1. Hasil citra Radiografi dengan arus dan waktunya $20 \mathrm{mAs}$ (a)tegangan tabung $60 \mathrm{kV}$, (b)tegangan tabung $65 \mathrm{kV}$, (c)tegangan tabung $70 \mathrm{kV}$, (d)tegangan tabung $75 \mathrm{kV}$ dan (e)tegangan tabung $80 \mathrm{kV}$.

Secara visual, citra phantom air dapat jelas terlihat ditunjukkan pada gambar 1 dengan penggunaan arus waktu $20 \mathrm{mAs}$. Citra yang ditunjukkan pada gambar 1 (a, b dan c) mempunyai kontras citra yang relatif tinggi, hal ini dapat dilihat dari kemampuan citra phantom untuk dibedakan terhadap background. Ketajaman citra yang dimiliki cukup tinggi sehingga tepi dan bagian dari objek dapat dideteksi dan dilihat dengan tajam. Gambar 14(a) dan gambar 14(b) dapat dikatakan citra yang bagus karena tidak ada nilai keabuan yang mendominasi pada hasil citra.

Pada Gambar 1(d) dan Gambar 1(e) objek tidak begitu jelas. Citra ini memiliki kontras yang rendah (nilai keabuan yang rendah), hasil citra cenderung gelap tidak dapat dibedakan antara objek dan background. Ketajaman citra rendah menyebabkan tepi dan bagian-bagian citra phantom tidak terdeteksi dengan tajam. Citra radiografi Gambar 1(d) dan Gambar 1(e) bisa dikatakan kualitas citra buruk.

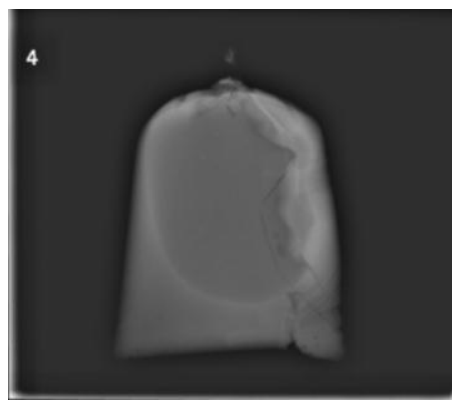

(a)

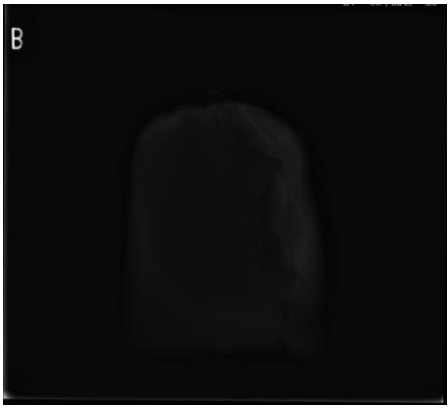

(b)

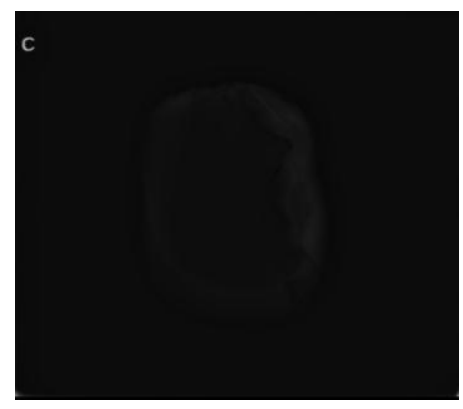

(c) 


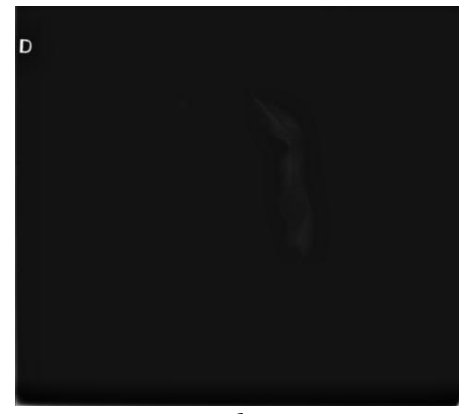

(d)

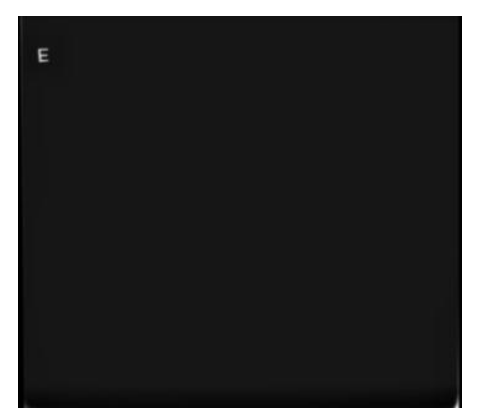

(e)

Gambar 2. Hasil citra Radiografi dengan arus dan waktunya 25 mAs (a)tegangan tabung $60 \mathrm{kV}$, (b)tegangan tabung $65 \mathrm{kV}$, (c)tegangan tabung $70 \mathrm{kV}$, (d)tegangan tabung $75 \mathrm{kV}$ dan (e)tegangan tabung $80 \mathrm{kV}$.

Ketajaman adalah kemampuan memperlihatkan batas yang tegas antara dua daerah yang memiliki kerapatan berbeda. Gambar 2(a) terlihat pada citra menunjukkan gradasi yang baik yaitu perbedaan putih terang hingga hitam keabuan yang sempurna dan perbedaan antara objek phantom dengan daerah sekitar objek. Kontras gambar 15(a) ini tergolong citra kontras bagus karena memperlihatkan jangkauan nilai keabuan yang lebar tanpa ada suatu nilai keabuan yang mendominasi.

Terlihat pada citra radiografi gambar 2(b) dan gambar 2(c) objek tidak begitu jelas, tetapi ketajaman tepi objek dan bagian objek dapat dideteksi. Citra ini memiliki kontras yang rendah karena hasil citra cenderung gelap, sehingga cukup sulit untuk dapat dibedakan antara objek dan background.
Visualisasi citra phantom pada gambar 2(d) objeknya tidak terlihat. Ketajaman tepi objek hanya terlihat $\pm 1 / 4$ bagian objek yang dapat dideteksi. Komposisi citra yang dimiliki terlalu gelap sehingga citra ini memiliki kontras yang rendah. Gambar 2(e) memiliki kontras dan ketajaman yang sangat rendah (buruk) dikarenakan citra yang dihasilkan tampak gelap sehingga objek tidak terlihat dari background. Penurunan kontras dan ketajaman ini disebabkan oleh semakin tingginya nilai tegangan tabung. Perubahan tegangan tabung sinar-X berpengaruh terhadap tingkat keabuan citra radiografi yang dihasilkan. Semakin tinggi tegangan yang digunakan maka tingkat keabuan yang dihasilkan semakin rendah (Muttaqin dan Susilo, 2017).

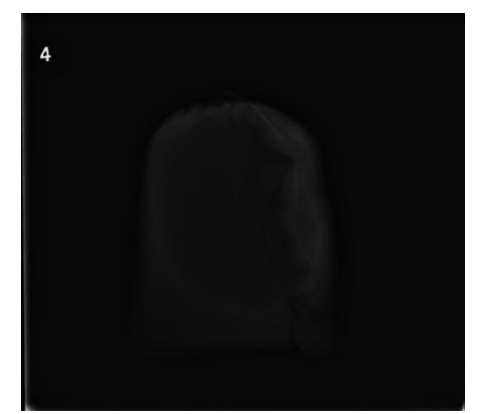

(a)

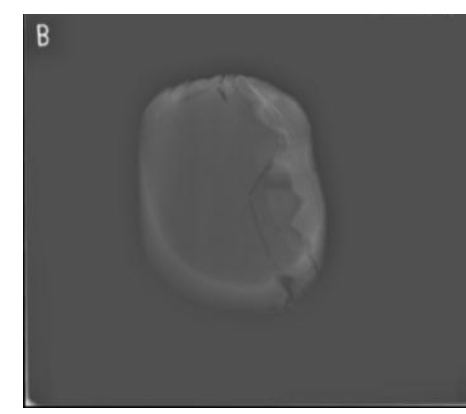

(b)

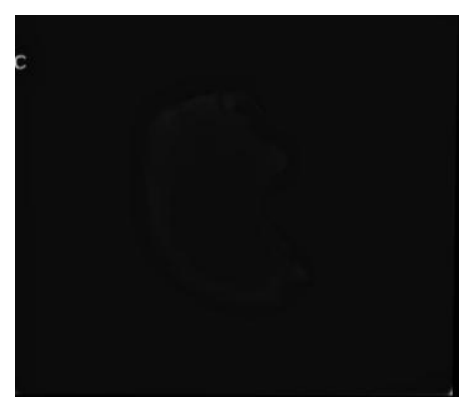

(c)
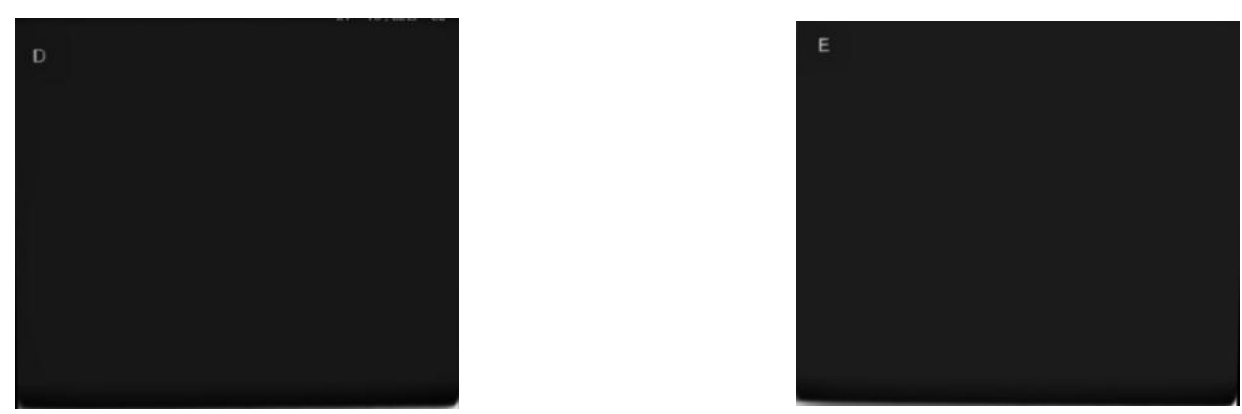
Gambar 3. Hasil citra Radiografi dengan arus dan waktunya $30 \mathrm{mAs}$ (a)tegangan tabung $60 \mathrm{kV}$, (b)tegangan tabung $65 \mathrm{kV}$, (c)tegangan tabung $70 \mathrm{kV}$, (d)tegangan tabung $75 \mathrm{kV}$ dan (e)tegangan tabung $80 \mathrm{kV}$.

Objek eksposi pada gambar 3(a) terlihat tetapi tidak terlalu tajam sehingga ketajaman dan kontras pada objek ini relatif rendah, begitupun dengan gambar 3(c) objek yang terlihat hanya $\pm 3 / 4$ bagian dari phantom dan tidak dapat dibedakan antara objek dengan background. Kontras yang dihadirkan pada citra ini tampak gelap.

Citra Gambar 3(b) memiliki kontras rendah, namun ketajaman yang cukup tinggi. Hal ini terlihat dari citra yang komposisi citranya dominan terang dan ada bagian objek yang terlihat menyatu dengan background, tetapi detail tepi objek phantom cukup jelas terlihat dan dapat dideteksi. Kemunculan citra yang dominan terang pada gambar 3(b) disebabkan oleh radiasi hambur yang dihasilkan ketika berkas sinar yang diterima oleh objek menyebabkan beberapa sinar-X terhambur, karena pengaruh tegangan tabung dan arus waktu yang digunakan memiliki nilai tinggi. Gambar 3(d) dan gambar 3(e) sama halnya dengan citra gambar 2(e). Pada citra tersebut, tidak dapat dideteksi batas tepi objek dengan background sehingga dapat dikatakan bahwa citra tersebut memiliki kontras dan ketajaman yang sangat rendah sehingga citra yang dihasilkan tampak gelap.

Daerah yang lebih gelap pada citra radiografi phantom merupakan representasi dari objek yang memiliki struktur lebih padat (tebal) sehingga memiliki daya serap besar yang dipengaruhi oleh perubahan tegangan tabung terhadap kuantitas dan kualitas sinar-X. Artinya ketika sinar-X menembus suatu objek maka akan terjadi interaksi antara objek dengan sinar-X sehingga sebagian besar sinar- $\mathrm{X}$ tersebut diserap oleh objek dan hanya sedikit saja sinar-X yang diteruskan dan menghasilkan citra radiografi yang tampak gelap. Sedangkan daerah yang lebih terang merupakan representasi dari obyek yang memiliki struktur lebih lunak (tipis) sehingga daya serap terhadap sinar-x kecil. Objek yang lebih lunak akan banyak meneruskan sinar-X dan sedikit menyerap sinar-X sehingga citra yang terbentuk berwarna lebih terang.

\section{Analisis Histogram Derajat Keabuan Citra Radiografi}

Dengan menggunakan software platform java Image-J Basics version 1.38 diperoleh histogram seperti pada gambar 4. Berdasarkan jenis distribusi sebenarnya, histogram cenderung ke sebelah kiri untuk semua variasi jumlah citra, sehingga citracitra tersebut cenderung gelap. Pada histogram 1 merupakan tampilan histogram gambar 1(a), terlihat bahwa terdapat dua daerah bobot distribusi gray level yaitu dimulai dari posisi piksel 0 sampai 47 yang menunjukkan citra latar background hitam, serta posisi 48 sampai 157 merupaka area letak objek phantom. Pada histogram tersebut, gray level pada posisi 48 sampai 157 merupakan daerah dimana masih bisa dimungkinkan untuk memperoleh informasi tentang citra. Persebaran gray level histogram 1 cukup merata ke kiri menuju daerah hitam. Dari histogram gray level ini citra mempunyai tingkat kecerahan (brightness) yang cukup

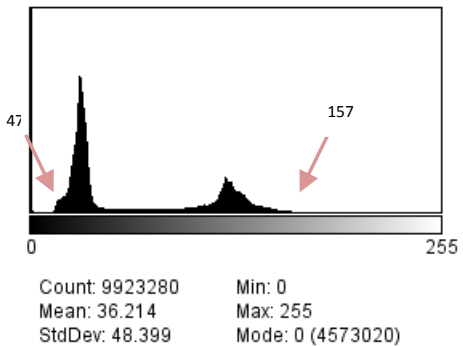

Histogram 1

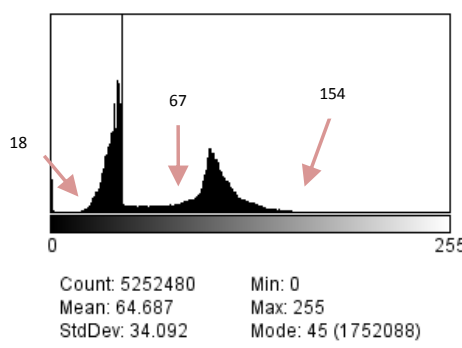

Histogram 2

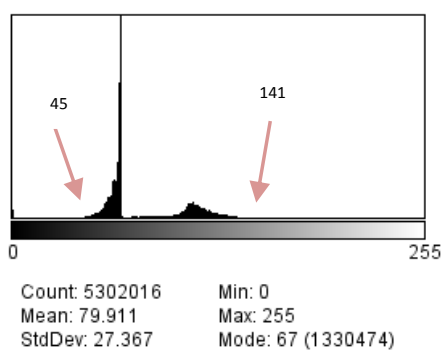

Histogram 3 


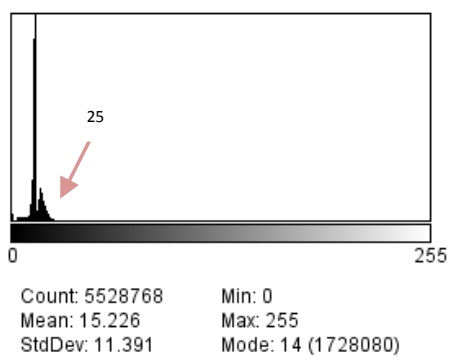

Histogram 4

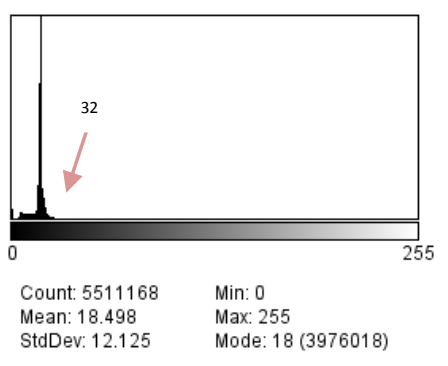

Histogram 5

Gambar 4. Tampilan histogram derajat keabuan citra radiografi dengan arus dan waktu 20 mAs, tegangan tabung $60 \mathrm{kV}, 65 \mathrm{kV}, 70 \mathrm{kV}, 75 \mathrm{kV}$ dan $80 \mathrm{kV}$.

Hitogram 2 adalah histogram derajat keabuan gambar 14(b). Daerah bobot distribusi gray level pertama pada posisi 18 sampai 67, merupakan bagian background (citra latar) yang berwarna hitam. Daerah bobot distribusi derajat keabuan yang lain pada posisi 68 sampai 144 merupakan representasi citra objek phantom yang mempunyai brightness yang cukup tinggi..

Distribusi gray level histogram 3 pada posisi 45 sampai 141 menunjukkan representasi citra objek phantom dan background. Tampilan histogram 3 merupakan derajat keabuan dari gambar 1(c) dengan distribusi gray level cenderung ke kanan menuju daerah putih. Pada histogram tersebut, terlihat bahwa citra mempunyai tingkat kecerahan tinggi.

Histogram 4 dan histogram 5 memiliki distribusi gray level yang berada disebelah kiri sehingga berakibat pada tampilan citra yang sangat gelap. Menurut Bushong (2001), kualitas citra radiografi yang baik adalah gambar yang mampu memberikan informasi yang jelas mengenai objek atau organ yang diperiksa. Histogram 4 dan histogram 5 merupakan citra gelap, sehingga tidak ada informasi yang bisa diperoleh dari citra. Citra yang berada di luar objek, nilai derajat keabuan pada jangkauan 0 sampai 5. Namun, distribusi gray level untuk histogram 4 dan histogram 5 memiliki distribusi yang berbeda-beda untuk masing-masing histogram. Histogram 4 merupakan tampilan derajat keabuan gambar 1(d) yang memiliki posisi gray level pada 0 sampai 25, sedangkan histogram 5 adalah tampilan derajat keabuan gambar 1(e) yang memiliki posisi gray level pada 0 sampai 32 .

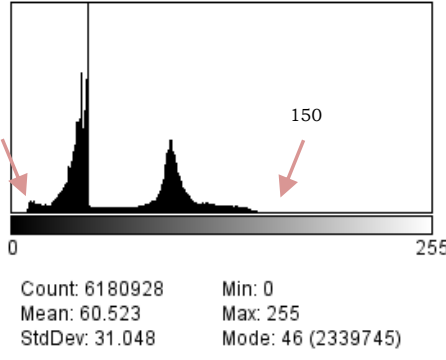

Histogram 6

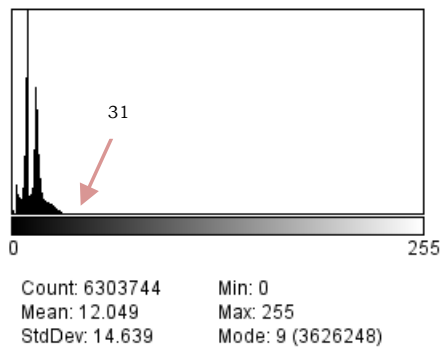

Histogram 7

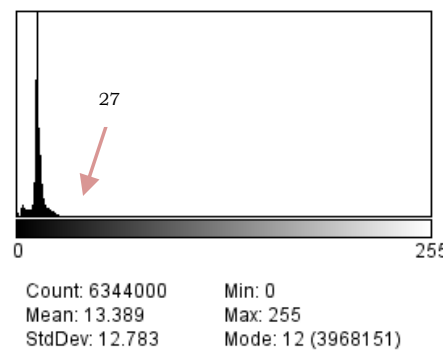

Histogram 8

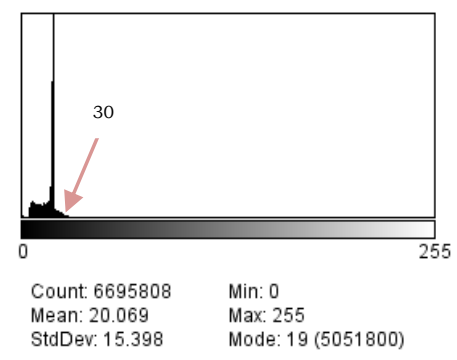

Histogram 9

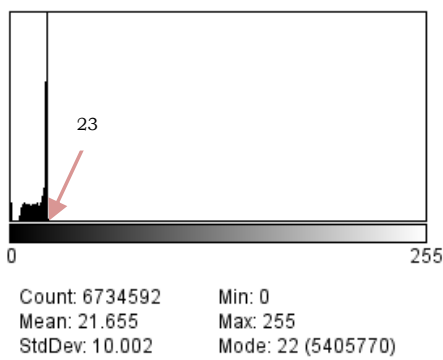

Histogram 10 
Gambar 5. Tampilan histogram derajat keabuan citra radiografi dengan arus dan waktu $25 \mathrm{mAs}$, tegangan tabung $60 \mathrm{kV}, 65 \mathrm{kV}, 70 \mathrm{kV}, 75 \mathrm{kV}$ dan $80 \mathrm{kV}$.

Hasil citra terbaik yang dapat dianalisis secara umum adalah citra yang memiliki distribusi derajat keabuan yang cukup luas dan merata, sedemikian sehingga setiap derajat keabuan memiliki piksel yang relatif sama (Ahmad, 2005). Luasnya derajat keabuan citra dipengaruhi oleh banyaknya intensitas sumber sinar-X yang menembus objek. Histogram 6 merupakan tampilan derajat keabuan gambar 2(a) yang memiliki distribusi gray level dari 7 sampai 140 . Dari analisa sebelumnya dapat dilihat bahwa pada gambar 2(a) memiliki kontras yang bagus karena memperlihatkan jangkauan nilai keabuan yang lebar. Citra radiografi dari gambar 2(a) memiliki informasi radiografi lebih baik sehingga dapat direkomendasikan sebagai citra radiografi yang baik untuk nilai ekposi yang optimum.

Histogram 7 memiliki distribusi gray level dengan posisi 0 sampai 31. Histogram ini adalah tampilan dari gambar 2(b) yang tidak begitu jelas terlihat objeknya. Tampilan histogram 7 terlihat di kanan yang memiliki gradasi warna hitam sehingga citra dominan terlihat gelap. Sama halnya dengan histogram 7 , histogram 8 juga memiliki gradasi warna hitam yang dominan. Histogram 8 menunjukkan tampilan dari gambar 2(c), distribusi gray level yang dimilikinya 0 sampai 27. Oleh karena itu, histogram 7 dan histogram 8 tidak dapat dibedakan tingkat kontras citranya.

Terlihat histogram 9 dan histogram 10 sama, nilai derajat keabuan terkonsentrasi disebelah kiri sehingga citra merupakan citra gelap. Namun, nilai jangkauan derajat keabuannya berbeda. Histogram 9 memiliki posisi gray level pada 0 sampai 30 yang merupakan tampilan derajat keabuan gambar 2(d), sedangkan histogram 10 posisi gray level pada 0 sampai 23 menunjukkan gambar

2(e).

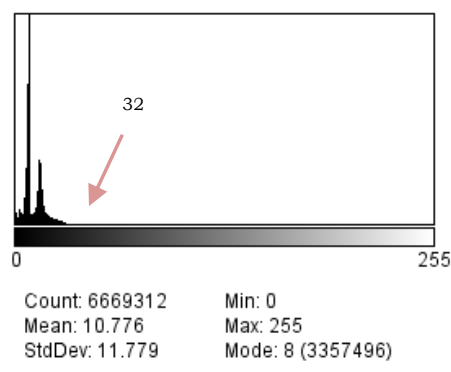

Histogram 11

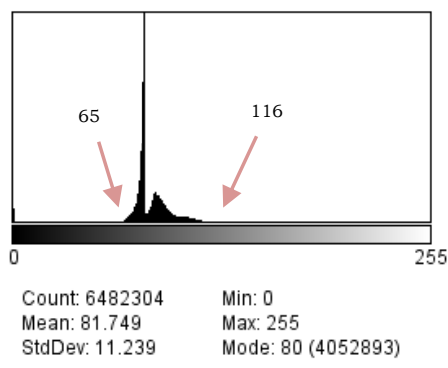

Histogram 12

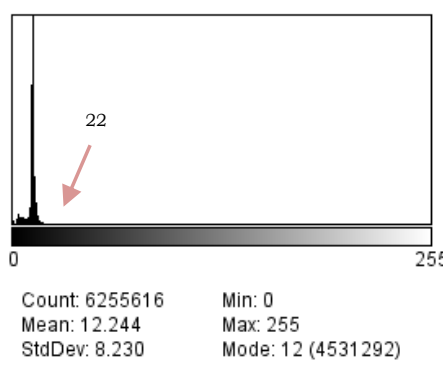

Histogram 13
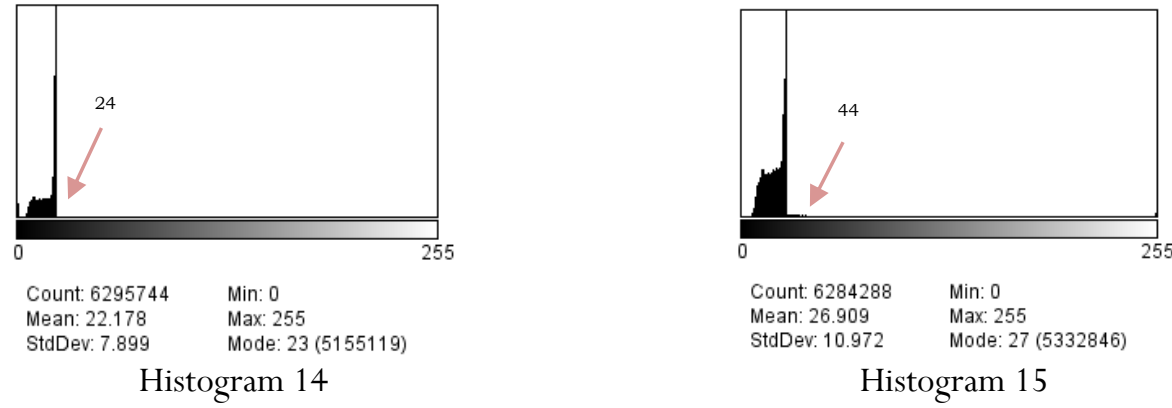

Gambar 6. Tampilan histogram derajat keabuan citra radiografi dengan arus dan waktu $30 \mathrm{mAs}$, tegangan tabung $60 \mathrm{kV}, 65 \mathrm{kV}, 70 \mathrm{kV}, 75 \mathrm{kV}$ dan $80 \mathrm{kV}$.

Histogram 11 merupakan tampilan histogram dari gambar 3(a). Adapun daerah bobot distribusi gray level berada pada posisi 0 sampai 32 pada daerah kiri histogram. Bobot distribusi daerah kiri merupakan bagian background yang berwarna hitam. Secara keseluruhan, bobot distribusi gray level terlihat lebih gelap. Dengan range yang sempit maka kecil untuk memperoleh informasi secara keseluruhan.

Histogram 12 adalah tampilan histogram citra gambar 3(b) yang terlihat secara visual memiliki kontras rendah, tetapi ketajaman yang cukup tinggi. Dari histogram yang terlihat, derajat keabuannya hanya menempati sebagian kecil atau terkelompok (clustered) dari rentang nilai-nilai 
keabuan. Distribusi histogram ini berada pada posisi gray level 65 sampai 115 .

Histogram 13 merupakan tampilan derajat keabuan dari gambar 3(c). Histogram ini berada pada daerah kiri yang hasil citranya tampak gelap. Daerah distribusi gray level berada pada posisi 0-22, sehingga citra yang terlihat tidak dapat membedakan antara objek dengan background.

Tampilan histogram 14 memiliki kemiripan dengan tampilan histogram 15. Nilai derajat keabuannya berada disebelah kiri sehingga tampak hasil citra gelap. Distribusi gray level yang dimiliki histogram 14 berbeda dengan histogram 15, posisi distribusi gray level histogram 14 yang menunjukkan tampilan citra gambar $16(\mathrm{~d})$ adalah 0 sampai 24. Sedangkan distribusi gray level histogram 15 berada pada posisi 0 sampai 44. Hasil citra dari dua histogram ini terlalu gelap, maka tidak ada informasi yang dapat diambil dari citra.

Berdasarkan hasil analisis citra penelitian ini, terlihat bahwa tegangan $80 \mathrm{kV}$ merupakan tegangan tertinggi dalam penggunaan faktor eksposi. Tampilan histogram dengan tegangan tabung $80 \mathrm{kV}$ keseluruhan citra menunjukkan area kehitaman berlebih dan tidak dapat dibaca pada tiap perlakuannya. Tegangan tinggi bisa mempercepat timbulnya citra pada proses eksposi, akan tetapi penggunaan tegangan tinggi akan memperbesar resiko radiasi yang diterima objek dan akan mempercepat kerusakan pada pesawat sinar-X karena terjadi peningkatan arus dan tegangan. Tegangan $80 \mathrm{kV}$ tidak dianjurkan penggunaannya meskipun bisa mempercepat waktu timbulnya citra. Dalam penelitian ini diketahui semakin tinggi nilai faktor ekposi tegangan tabung maka menghasilkan kontras gambar yang gelap.

Semakin tinggi besar tegangan tabung yang diberikan dapat mengurangi nilai kontras. Hal itu disebabkan oleh semakin banyaknya intensitas sinar-X yang diterima oleh radiografi sehingga variasi kehitaman pada radiografi akan menurun. Perubahan tegangan tabung akan berpengarauh terhadap kuantitas dan kualitas sinar-X. Peningkatan tegangan kerja tabung mempengaruhi intensitas dan ukuran daya tembus sinar-X. Kecepatan gerak elektron bertambah sesuai dengan naiknya tegangan tabung dan mempengaruhi daya tembus sinar-X (Jauhari, 2008). Tegangan tabung sinar-X merupakan faktor yang dominan dalam penentuan tingkat energi sinar-X yang dihasilkan guna menembus objek yang akan di eksposi, sehingga akan berpengaruh pada variasi tingkat energi radiasi sinar-X yang ditangkap oleh radiograf. Variasi tingkat energi tersebut dapat memberikan perbedaan nilai intensitas radiasi sinar-X objek satu dengan objek lainnya sehingga timbul kontras pada citra radiografi.

Kegiatan ini menentukan perubahan arus akan meningkatkan pergerakan muatan elektron dari kutub katoda menuju kutub anoda dalam pembentukan sinar-X yang sangat dipengaruhi oleh tegangan dan hambatan. Sumber tegangan dan arus dalam penelitian ini terkendali sesuai output tegangan dan arus yang ada pada pesawat sinar-X. Nilai tegangan $60 \mathrm{kV}$ merupakan nilai ideal dalam penelitian dikarenakan sudah memenuhi kualitas citra radiografi yang baik sehingga gambar radiografi dapat dibaca atau diinterpretasikan dengan mudah. Hal ini merupakan hasil penelitian yang baru sebagai upaya untuk meningkatkan hasil kualitas citra radiografi dengan meminimalkan dosis paparan radiasi yang diserap.

\section{SIMPULAN DAN SARAN}

Berdasarkan penelitian pengaruh faktor eksposi terhadap kualitas citra radiografi yang dilakukan maka dapat disimpulkan bahwa semakin tinggi besar tegangan tabung, arus dan waktu yang diberikan dapat mengurangi nilai kontras, kuantitas dan kecerahan citra radiografi.

Faktor eksposi yang paling optimum diberikan terhadap kualitas citra radiografi pada tegangan tabung $60 \mathrm{kV}$ waktu arus $25 \mathrm{mAs}$ karena citra radiografi dapat dibaca dan sudah memenuhi kualitas citra yang baik.

\section{UCAPAN TERIMA KASIH}

Terima kasih kepada RSUD Raden Mattaher Jambi dan Universitas Jambi khususnya Fakultas Sains dan Teknologi yang telah memberikan fasilitas kepada peneliti sehingga penelitian ini dapat terlaksana.

\section{DAFTAR PUSTAKA}

Ahmad, U. 2005. Pengolahan Citra Digital dan Teknik Pemrogramannya. Graha Ilmu. Yogyakarta.

Bushong, S. 2001. Radiologic Science for Technologist Physics Biology and Protection. The CV Moscby Company. Washington DC.

Dewi, G. S. N. 2009. Evaluasi Radiografis Letak Foramen Mentalis Antara Suku Jawa dan Suku Papua di Jember. Jember: Fakultas Kedokteran Gigi Universitas Jember.

Dhahryan. dan M. Azam. 2009. Pengaruh Teknik Tegangan Tinggi Entrasce Skin Exposure (ESE) dan Laju Paparan Radiasi Hambur 
Pada Pemeriksaan Abdomen. Jurnal Berkala Fisika. ISSN:1410-9662 Vol. 12, No. 1.

Jauhari, Arif. 2008. Berkas sinar-X dan Pembentukan Gambar pada Sinar-X. Puskaradim. Jakarta.

Mutaqqin, R. Dan Susilo. 2012. Uji Banding Kualitas Citra Radiograf Sitem Radiografi Digitak Modifikasi Terhadap Computed Radiogrphy System dengan Metode Contrass to Noise Ratio. Physics Communucation.
Semarang. ISSN:2528-5971. Vol 1, No 1.

Rasad, Sjahriar. 2005. Radiologi Diagnostik. Edisi kedua. Badan penerbit FKUI. Jakarta.

Sartinah, Sumariyah, dan N. Ayu. K. U. 2008. Variasi Nilai Eksposi Aturan 15\% pada Radiografi menggunakan Imaging Plate untuk mendapatan Kontras Tertinggi. Jurnal Berkala Fisika. ISSN:1410-9662 Vol.

11 ,

No.

2. 